\title{
O Brasil e a Argentina entre a cordialidade oficial e o projeto de integração: a política externa do governo de Ernesto Geisel (1974-1979)*
}

\section{MATIAS SPEKTOR**}

Em 15 de março de 1979, dia da posse do presidente João Baptista Figueiredo, um encontro de alto nível entre as diplomacias argentina e brasileira selou a decisão de solucionar o contencioso pela utilização dos recursos hídricos da Bacia do Prata. Menos de seis meses mais tarde, as chancelarias dos dois países acordavam a normalização de suas relações, turvadas havia mais de um decênio.

Inesperadamente, um projeto inovador ganhava vida no Cone Sul, ao redefinir o cenário regional em seus aspectos estratégico-militar, econômico e político. Tratava-se de um paradoxo: no momento mesmo em que a estratégia do nacionaldesenvolvimentismo brasileiro começava a perder o fôlego devido à crise financeira da década de 1980, a diplomacia ultrapassava seu último desafio crucial na região - a normalização das relações com a Argentina em uma amizade calcada na concertação política e, em seguida, na integração comercial.

Quais são os antecedentes desse fenômeno? Como foi possível que surgisse um projeto integracionista fundacional nas relações internacionais do Cone Sul apenas finda a negociação da hidrelétrica de Itaipu, um dos momentos mais turbulentos do relacionamento bilateral no século XX? Quais foram os motivos que levaram a diplomacia brasileira a promover semelhante empresa?

A interpretação aqui proposta sugere que o projeto de integração regional iniciado na década de 1980 foi o resultado não-intencional da conjuntura crítica que acometeu a política externa brasileira para a Argentina entre 1974 e 1979, qual fosse a sistemática ruptura dos princípios e concepções que informaram a

Rev. Bras. Polít. Int. 45 (1): 117-145 [2002]

* Este artigo é extensivamente baseado em minha dissertação de mestrado, Ruptura e Legado: o colapso da cordialidade oficial e a construção da parceria entre o Brasil e a Argentina (1967-1979). Universidade de Brasília. 2002.

** Mestre em Relações Internacionais pela Universidade de Brasília. 
atuação diplomática do país para o seu vizinho ao sul desde princípios do século XX. Argumenta-se que, entre 1974 e 1979, Ernesto Geisel e seu chanceler, Antônio Francisco Azeredo da Silveira, puseram em xeque o lugar da Argentina no cálculo estratégico da política exterior brasileira, questionando a validez do típico marco conceitual do Itamaraty para orientar as relações com Buenos Aires - a cordialidade oficial.

A cordialidade oficial representa o conjunto de princípios e concepções ${ }^{1}$ que informou a diplomacia brasileira para Buenos Aires com o objetivo primordial de evitar que a dinâmica entre os dois principais poderes da América do Sul levasse a uma rota de colisão. Esse apanhado de orientações pode ser resumido por (a) uma postura tolerante em relação ao elevado perfil da diplomacia argentina em assuntos regionais, hemisféricos e globais, (b) a sistemática busca de faixas de cooperação com aquele país no intuito de diluir potenciais desentendimentos, (c) a inclusão da Argentina nas iniciativas internacionais do Brasil, e (d) a promoção de bons ofícios entre Buenos Aires e Washington sempre que o sensível relacionamento entre as duas capitais apontasse para o confronto ${ }^{2}$.

Sustenta-se que a ruptura com o paradigma, durante o governo de Geisel, foi sistemática, isto é, (i) as quatro dimensões do mesmo foram negadas, (ii) ocorreu homogeneamente ao longo de todo o mandato presidencial e, (iii) uma vez finda a administração do general, o Brasil encontrou-se sem marco de referência no qual racionalizar o vínculo com o vizinho, tarefa à qual se dedicaram os governos subseqüentes mediante a gestação de um projeto de integração regional.

O processo de mudança teve início, contudo, antes da posse de Geisel, quando, em 1967, o debate pela utilização dos trechos internacionais da Bacia do Prata ganhou contornos de discordância frontal entre os dois países ${ }^{3}$. Foi sobre o uso das águas que a validade da tradicional estratégia brasileira para a Argentina foi revisada.

Imediatamente após a resolução formal do contencioso, em 1979, o Itamaraty de Ramiro Saraiva Guerreiro (1979-1985) encaminhava os negócios bilaterais a um equilíbrio calcado em um novo projeto internacional para o Brasil, momento em que a Argentina ocupou um lugar primordial, senão o mais relevante, na política externa brasileira. Nascia uma nova racionalidade no marco conceitual da política externa brasileira e, com ela, um inusitado ordenamento regional a caracterizar a política internacional da América do Sul na década de 1990.

Este artigo está organizado em blocos. Inicialmente, apresenta o marco teórico-metodológico no qual foi analisada vasta gama de documentos primários. Em seguida, a cordialidade oficial é conceitualizada à luz da literatura especializada sobre o eixo bilateral argentino-brasileiro. Enfocam-se, na seqüência, os mecanismos que levaram a seu gradual abandono, e passa-se em revista a incipiente reação argentina aos inesperados movimentos do Brasil, o processo negociador entre Azeredo da Silveira e Oscar Camilión, o impacto que sobre ele tiveram a redefinição 
da política externa norte-americana para a América Latina, a participação da imprensa brasileira na dinâmica da negociação e os respectivos processos políticos domésticos. Finalmente, recupera-se a evolução do lugar da Argentina no quadro conceitual da diplomacia brasileira nos primeiros anos de 1980 e apresentam-se os mecanismos de produção e reprodução que alimentaram o projeto bilateral de integração ao longo da década de 1990.

\section{O estudo sistemático das mudanças: o modelo da conjuntura crítica}

O modelo proposto para conduzir esta análise - a conjuntura crítica ${ }^{4}$ - é oriundo da história comparada e tem por meta oferecer critérios para avaliar processos de mudança. A sua lógica articula-se de modo a sugerir que só é possível identificar rupturas significativas ao longo do tempo se as mesmas conformam um período histórico específico e inauguram, após seu encerramento, um período substancialmente distinto daquele sobre o qual atuaram originalmente. Em outras palavras, uma conjuntura crítica é um momento limitado durante o qual mudanças geram um legado específico.

Segundo essa vertente, os critérios para identificar rupturas de forma sistemática são três: (a) a existência de uma delimitação temporal da hipotética ruptura, ou seja, a identificação clara do período em que uma mudança começa e termina; (b) a ocorrência, identificável, de uma tendência ou regularidade prévia à ruptura observada, que é a base sobre a qual a mudança opera; e (c) a ocorrência de legados oriundos da suposta ruptura, ou seja, fenômenos que têm lugar imediatamente após a conclusão da mudança observada e instauram padrões inovadores. Caso um desses pré-requisitos esteja ausente, o processo de transformação fica descaracterizado como tal e pode-se falar apenas em "inflexão" ou mudança limitada, mas não em ruptura com o passado.

Paralelamente à noção de conjuntura crítica, utilizou-se a categoria de homem de Estado ${ }^{5}$ para interpretar a ação internacional das personalidades no entendimento de que o ideário dessas lideranças impregna sua ação, suas escolhas e, conseqüentemente, as relações entre as burocracias e os países ${ }^{6}$.

$\mathrm{O}$ argumento aquí apresentado sugere, portanto, que a ruptura promovida pelo governo Geisel em relação à Argentina (a conjuntura crítica) fez com que certos resultados (a parceria estratégica a partir dos anos 1980) tenham sido mais prováveis naquele momento histórico e com aquela intensidade do que se a cordialidade oficial não fosse posta à prova.

\section{Fontes intelectuais e evolução da cordialidade oficial}

Durante a primeira metade do século XIX, o Brasil utilizou o esforço de guerra como instrumento recorrente na defesa dos interesses definidos pela corte 
do Rio de Janeiro. O cálculo estratégico brasileiro era significativamente moldado em função das posições defendidas por Buenos Aires, principal poder capaz de fazer-lhe oposição e turvar o seu horizonte regional. Exemplos disso são os esforços de guerra empreendidos pelo Brasil na criação do Estado do Uruguai (1828) ${ }^{7}$ e na eliminação de Rosas (1852) ${ }^{8}$ e nas movimentações que desembocaram na Guerra do Paraguai (1865-1870) ${ }^{9}$.

Foi durante esse último conflito armado que a estrutura regional de poder até então conhecida atravessou as mudanças que consolidariam, pela primeira vez, a preeminência de Buenos Aires no Prata ${ }^{10}$. O fim da Guerra do Paraguai definia um novo quadro em que a Argentina sobressaía pelo inédito crescimento financeiro do capital privado, o rearmamento de suas forças e a articulação de seus interesses na América do Sul mediante uma vasta rede de relacionamentos bilaterais fluidos ${ }^{11}$.

As preocupações impostas à diplomacia brasileira pelo novo perfil da diplomacia Argentina ganharam o debate público no Rio de Janeiro, onde as questões do Prata eram tratadas vivamente no Parlamento imperial ${ }^{12}$. O homem responsável por advogar o redirecionamento da política externa brasileira nesse contexto foi José Maria da Silva Paranhos, o Visconde do Rio Branco ${ }^{13}$.

O Visconde advogava que, em assuntos regionais, o Brasil devia mostrarse "moderado, benévolo e generoso", sob pena de suscitar desconfianças, entre os países lindeiros, excessivamente custosas. A proposta visava a diluir a percepção generalizada, especialmente entre os países menores, de que o Brasil era um elemento potencialmente hostil ao status quo territorial da América do Sul. Essa percepção, associada ao estranhamento que o país causava devido ao lusitanismo e à filiação monárquica em um teatro de repúblicas hispânicas, deveria ser evitada mediante a construção de interesses comuns facilitados pelo comércio, as finanças e o amansamento do discurso diplomático. $\mathrm{O}$ alvo de suas recomendações era a política para a Argentina. Em seu pensamento, o fato de a instabilidade e a competição predatória caracterizarem o cenário político argentino impunha ao Brasil a responsabilidade de manter uma orientação compreensiva e generosa capaz de evitar as asperezas inerentes ao relacionamento entre as duas forças da região ${ }^{14}$.

Já nesse momento, estavam dadas as condições intelectuais para a gestação de duas vertentes da cordialidade oficial: a postura tolerante em relação ao elevado perfil da diplomacia argentina e a busca sistemática por faixas de cooperação comercial e política com esse vizinho. Esperava-se diluir, mediante esses mecanismos, o potencial perturbador que a Argentina exercia sobre a política externa brasileira no contexto da nova estrutura política da América do Sul.

A intensificação dessa agenda coube ao Barão de Rio Branco, filho do Visconde, quem entre 1902 e 1912 procurou definir as bases do eixo Rio de Janeiro - Buenos Aires sobre um condomínio de poder que permitisse gerenciar uma estrutura estável de paz abaixo da linha do Equador. Embora sua proposta de um 
pacto defensivo entre Argentina, Brasil e Chile tenha fracassado, em 1904, devido à oposição do governo de Buenos Aires, dez anos depois, em 1914, os três países assinaram um tratado de cordial inteligência política e arbitragem que selaria a paz por anos. É plausível supor que, para o Barão, esse fosse um instrumento de garantia contra o perfil muitas vezes errático e denuncista da diplomacia argentina. Ao reconhecer interesses paralelos permanentes entre as duas nações e ao incorporar Buenos Aires e sua tradicional rival, Santiago, em um arranjo único, ficavam diluídos os possíveis efeitos deletérios da política exterior de Buenos Aires sobre a política regional do Rio de Janeiro.

O resultado da política do Barão para a Argentina provou ser duradouro e esteve no centro mesmo da redefinição da diplomacia brasileira para Buenos Aires na década de 1970: suas bases foram o princípio da liberdade de navegação no Prata $^{15}$ e o reconhecimento tácito das relações preferenciais entre Argentina e Paraguai ${ }^{16}$, por um lado, e Brasil e Uruguai, por outro.

Nascida em finais do século XIX, a cordialidade oficial também foi testemunha do surgimento da nova potência hemisférica, os Estados Unidos, fenômeno que viria a condicionar a vida internacional da América do Sul a partir de então. Os preceitos do Visconde do Rio Branco foram, assim, adaptados para lidar com uma das interações mais perturbadoras das relações internacionais da região nos últimos cem anos: as posições divergentes de Argentina e Brasil face aos Estados Unidos.

Ainda na década de 1880, Buenos Aires e Washington emitiam sinais de que seu relacionamento seria traumático para o conjunto da América Latina. Tratava-se da bandeira antiianque içada pela Argentina durante a I Conferência Pan-Americana (Washington, 1889) no intuito de formar uma plataforma de resistência à expansão territorial dos Estados Unidos rumo ao Pacífico e à gestação da sua hegemonia no Caribe ${ }^{17}$. Ao opor a Doutrina Drago ${ }^{18}$ ao Corolário Roosevelt da Doutrina Monroe $^{19}$, a delegação argentina conseguiu elevar-se à qualidade de interlocutora de primeira linha em assuntos hemisféricos ${ }^{20}$. Na resistência aos Estados Unidos, a Argentina encontrou uma causa internacional suficientemente dramática para garantir-lhe audiência permanente junto às repúblicas americanas de maneira mais ou menos homogênea até a década de 1960. Sobre essa lógica operou a cordialidade oficial. Ao tirar proveito da discórdia argentino-estadunidense, o Brasil concebeu sua diplomacia como catalisadora do diálogo entre dois países centrais de seu horizonte externo. De tal sorte, a promoção dos bons ofícios fez do Itamaraty elemento necessário para a concertação política em nível hemisférico ${ }^{21}$.

A agenda da cordialide oficial ganharia renovado fôlego na década de 1930, quando adveio a diplomacia do desenvolvimento na América Latina ${ }^{22}$, qual fosse a instrumentalização dos vínculos internacionais em prol do incipiente esforço de desenvolvimento industrial. Nesse ambiente, Argentina e Brasil fizeram escolhas internacionais essencialmente díspares, que terminariam por conduzi-los a resultados 
substancialmente distintos ao fim do conflito mundial encerrado em 1945. Enquanto o Estado Novo enterrava a era das oligarquias no Brasil, o golpe militar na Argentina outorgava o poder aos interesses agropastoris e punha fim à seqüência de governos liberais. Naquele país, a vertente externa levou ao abandono da identidade latinoamericana conforme desenhada nos primeiros anos do século XX, assim como ao retorno de relações preferenciais com a Europa na falida tentativa de emular os sucessos que o projeto nacional havia experimentado durante a Belle Époque ${ }^{23}$.

Os temas em pauta que ocupavam as diplomacias dos dois poderes sulamericanos não eram novos: o equilíbrio de poder no Prata, a gestação de um ordenamento regional legítimo e a resolução dos contenciosos comerciais. A resposta brasileira para esses desafios foi o fortalecimento da cordialidade oficial: quando o equilíbrio de poder foi sujeito à Guerra do Chaco entre Bolívia e Paraguai (19321935), Argentina e Brasil mantiveram o nível de entendimento apesar das desconfianças do Rio de Janeiro em relação às verdadeiras intenções do Presidente Justo ${ }^{24}$.

A série de visitas presidenciais devida a esse assunto evidencia ter sido percepção corrente que a reconstrução da paz dependia da legitimidade que os dois grandes emprestassem à resolução final do conflito. A legitimidade da ordem regional, desafiada sistematicamente desde a primeira década do século XX pelas incessantes erupções do armamentismo, chegava a um fim mediante o consenso dos grandes e a anuência dos pequenos. Argentina, Brasil, Chile, México, Paraguai e Uruguai assinavam o Tratado Antibélico de Não-Agressão e de Conciliação (Rio de Janeiro, 1933), também conhecido como Pacto Saavedra-Lamas. A sombra da corrida armamentista no Cone Sul era progressivamente dissipada sob a noção de que o encontro de marcos de referência comuns em assuntos regionais diminuiria as incertezas inerentes à vida internacional ${ }^{25}$.

Ressurgia então a proposta brasileira de uma união aduaneira aberta à adesão dos vizinhos, agenda que as diplomacias formalizariam mediante tratado comercial em 1941. Dessa forma, o Brasil respondia ao perfil declaradamente europeísta da políticia comercial argentina mediante a oferta de um programa comum de comércio que banisse a tentação das desvalorizações competitivas (beggar thy neighbour), tão comuns na Europa. Vingava, na política do Itamaraty para a Argentina, a percepção segundo a qual o caminho das hostilidades, mesmo restrito ao campo comercial, seria prejudicial aos interesses brasileiros e, portanto, era dever brasileiro precaver-se mediante fórmulas de consenso com o vizinho.

O entreguerras constitui, assim, um período no qual a busca insistente por faixas de coincidência guiou a política do Itamaraty para Buenos Aires. Em um clima de desconfianças bilaterais e de redefinição dos perfis produtivos e diplomáticos - conjuntura na qual a busca de solidariedades é pouco provável - a concertação política de alto nível constituiu-se como rota possível e efetivamente procurada pela diplomacia brasileira em sua vertente austral. Em síntese, à época 
em que os projetos internacionais dos dois países se estranhavam, e ganhava forma a diplomacia brasileira para o desenvolvimento, a cordialidade oficial foi o elemento estabilizador das turbulências inerentes às relações entre Argentina e Brasil.

Porém, durante a II Guerra Mundial a cordialidade oficial foi contaminada pelo fenômeno do nacional-populismo. Dos dois lados do Prata, o carisma dos mandatários foi testado pela força das paixões mobilizadoras que marcam todo o período. Uma fonte de preocupação para o Rio de Janeiro nesse contexto eram as táticas utilizadas por Juan Domingo Perón ${ }^{26}$ para angariar apoios na região. Pouco a pouco, o guia de atuação para Buenos Aires perdeu a legitimidade nas práticas do Itamaraty e cedeu às percepções que, simultaneamente, temiam e evitavam associar o Brasil à Argentina de Perón. Esse período da história do eixo bilateral foi batizado por Cervo de diplomacia da obstrução ${ }^{27}$. Entre 1947 e 1948, o Palácio San Martín, sede da chancelaria argentina, havia estabelecido densas agendas com Bolívia, Colômbia, Equador, Paraguai, Peru e Venezuela, países em que a diplomacia brasileira acreditava haver ações desestabilizadoras de Perón. Efetivamente, as legações argentinas nas capitais sul-americanas incluíam, à época, um corpo de adidos diplomáticos para as áreas militar, policial, naval e sindical. ${ }^{28}$. A atualização da política externa peronista previa, além disso, o estabelecimento de relações com Cuba, Coréia do Norte, Vietnã do Norte e Alemanha Oriental, em uma afronta aberta à liderança norte-americana em assuntos hemisféricos.

A documentação primária disponível oferece indícios de que, no intuito de esquivar as resistências do Itamaraty ao seu diálogo com Perón, Vargas utilizou agentes pessoais que serviram de elo. Contudo, as tentativas de Vargas foram malogradas e, em vez de criar confiança, decepcionaram Perón. Por exemplo, entre 1945 e 1951, Perón fez quatro propostas de associação com o Brasil e o Chile em uma reedição do Pacto ABC, dessa vez com conteúdos comerciais, de complementação econômica e de integração física. Nas quatro ocasiões, a reação brasileira foi a não-resposta ${ }^{29}$, o que terminaria por irritar Perón profundamente e concorrer para a crise institucional que se abateu sobre o Brasil nos últimos meses da vida de Vargas $(1954)^{30}$.

Em suma, o conflito internacional que abalou o mundo entre 1939 e 1945, impôs um desafio e uma oportunidade peculiares à política continental do Brasil. Por um lado, deixou-o na desconfortável e delicada situação de posicionar-se a favor dos Estados Unidos sem melindrar o relacionamento com a Argentina sob pena de tornar-se vítima do discurso peronista de caráter redentor. Por outro, possibilitou ao Rio de Janeiro colocar-se sobre o embate de seus dois eixos diplomáticos fundamentais, Argentina e Estados Unidos, e ganhar posições face a esses dois parceiros.

Essa dimensão do comportamento brasileiro ganhou impulso durante a Conferência de Chapultepec (1945), na qual foi negociado o novo modelo de cooperação hemisférica e da qual o Departamento de Estado conseguira excluir 
Buenos Aires. Segundo a literatura brasileira ${ }^{31}$, a diplomacia do Itamaraty trabalhou para garantir que a Argentina pudesse aderir à Carta da conferência, evento que criou as condições para que pudesse mais tarde participar das Nações Unidas. Segundo essa produção, o presidente Eurico Gaspar Dutra (1946-1951) teria se negado a dar vida a um novo ordenamento sem a participação de Buenos Aires ${ }^{32}$. Parte da literatura argentina, todavia, argumenta que o Brasil foi, efetivamente, uma força obstrutora das possibilidades internacionais argentinas no imediato pósguerra $^{33}$. Outros afirmam que toda a América Latina isolou a Argentina em seu neutralismo, até que vieram em seu resgate nos instantes finais da Guerra ${ }^{34}$.

Mas entre 1956 e 1966, a cordialidade oficial foi voluntariosamente recuperada pela diplomacia brasileira. O seu retorno foi marcado pela dramática evolução das políticas exteriores de ambos os países face ao perigo do comunismo na América Latina e às alternativas que Juscelino Kubitschek (1956-1960) e Frondizi (1959-1962) ofereceram, sem sucesso, aos Estados Unidos. Mediante duas iniciativas internacionais de envergadura inédita no Cone Sul, Argentina e Brasil utilizaram o marco referencial do desenvolvimentismo para conformar um pólo ideológico e econômico ao sul do Continente. A primeira - Operação PanAmericana (OPA, 1959) - lançava a proposta de dar um caráter eminentemente econômico à política internacional das Américas como solução aos desafios impostos pela União Soviética, sugestão que seria implementada por meio de uma agenda de concertação política continental ampla e geral ${ }^{35}$. Apesar do fracasso em fundar um novo ordenamento regional, a OPA precedeu a concepção argentino-brasileira de que o Cone Sul poderia ser, efetivamente, um pólo atrativo da atenção internacional por oposição ao Caribe, que graças ao novo regime castrista tornarase o ponto de gravidade dos assuntos interamericanos. Essa pauta seria lançada a público por uma segunda iniciativa, que passou à história das relações bilaterais como o espírito de Uruguaiana $(1961)^{36}$.

Três eram os objetivos principais de Uruguaiana: o estabelecimento de uma sistemática de consulta política de alto nível; a coordenação das posições de ambos os países em foros internacionais; e a troca de informações sensíveis aos respectivos projetos nacionais de desenvolvimento. As idéias que originaram a pauta dos encontros foi desenhada, originalmente, por uma equipe de jovens diplomatas argentinos ligados diretamente ao novo mandatário. Do fracasso prematuro de Uruguaiana até o fim da década, a cordialidade oficial minguou no quadro conceitual da diplomacia brasileira.

Vários fatores contribuiram para isso. Em primeiro lugar, vale mencionar o avanço do programa diplomático de multilateralização da política externa brasileira que os governos militares implantaram sistematicamente desde $1967^{37}$. Desde aquele ano, a vertente externa do desenvolvimento - que já vinha sendo ensaiada desde Vargas - transformou-se em efetivo instrumento do expansionismo econômico brasileiro. Após décadas de ensaio, as relações do Brasil com a região 
poderiam ser finalmente instrumentalizadas em favor do desenvolvimento industrial do país ${ }^{38}$. A integração física tornava-se uma força permanente na política externa brasileira $^{39}$, motivo pelo qual a América Latina teria que deixar de ser problema estratégico e passar a ser instrumento de fortalecimento da economia do país. Não havia espaço para uma postura preventiva em relação a Buenos Aires.

Outro fenômeno gerador do esgotamento do modelo da cordialidade oficial foi o crescente pendor do equilíbrio de poder em favor do Brasil. Observando a evolução da política internacional sul-americana, durante a década de 1960, sob perspectivas geopolíticas, diplomáticas ou econômicas, conclui-se que a preeminência no Prata havia sido efetivamente rompida favoravelmente a Brasília, que poderia atuar na região sem temer um levante hispano comandado desde o Palácio San Martin ${ }^{40}$.

O terceiro sinal que aponta para o encerramento das condições de existência da cordialidade oficial é a redefinição dos vínculos de Argentina e Brasil com os Estados Unidos. Quando a questão cubana assumiu dimensões globais, em 1962, o Presidente argentino Guido respondeu ao pedido de solidariedade de John Kennedy mediante o envio de destróieres e uma esquadra de aviões para o esforço de bloqueio à ilha. Evidenciando o crescente desconforto brasileiro com a política de convergência historicamente alimentada pelo Itamaraty em relação ao Departamento de Estado, Goulart negou-se a colaborar com forças nacionais para essa empreitada. Violando a tendência histórica, é a Argentina dos anos sessenta o país em busca de status de aliado chave dos Estados Unidos na região ${ }^{41}$. A promoção de bons ofícios entre Buenos Aires e Washington, uma das vertentes que animava a atuação brasileira desde a chancelaria do Barão de Rio Branco, perdia relevância. A tendência argentina ao alinhamento automático contrastava com a crescente distância que Brasília procurava em relação ao seu próprio passado. Não havia mais espaço para que o Brasil temesse os efeitos da denúncia do intervencionismo, expansionismo ou pró-ianquismo inerentes às "relações especiais" com os Estados Unidos.

Finalmente, os sinais conjunturais que apontam a década de 1960 como o ocaso da tradicional vertente diplomática para o vizinho ao sul e, mais especificamente, o ano de 1966, concentram-se em torno da questão do aproveitamento hídrico do Prata. Em 1966, o Itamaraty assinou a Ata de Iguaçu com o Paraguai e, dessa forma, frustrou o argumento jurídico defendido pela Argentina segundo o qual toda obra hidráulica realizada em um rio internacional deveria ser submetida à consulta prévia do país a jusante. Seguindo essa idéia, conclui-se que o Brasil via-se diante de condições concretas para avançar a sua agenda regional, mesmo que isso envolvesse enfrentar a Argentina. Note-se que a última vez em que a diplomacia brasileira tinha deparado essa configuração de forças havia sido à época do Império ${ }^{42}$. 
Em suma, a cordialidade oficial é fundacional no Brasil: refere-se às possibilidades mesmas da presença brasileira na região. Se, durante o Império, as técnicas utilizadas calcavam-se na medição de forças, em ultimatos e em dinâmicos esquemas de alianças bilaterais, o Brasil republicano ensaiou administrar o desafio argentino no melhor espírito concertador. O acompanhamento histórico da mesma revela que essa forma de lidar com os desafios impostos pela Argentina foi adaptada pelo Itamaraty de forma flexível ao longo do tempo. Seja no esforço de definição dos mapas nacionais, na articulação dos interesses do desenvolvimento, na busca de benefícios da Grande Guerra, na definição do sistema interamericano ou na sua participação na Guerra Fria.

A exceção à regularidade foi a diplomacia da obstrução (1946-1955), período no qual o governo brasileiro malogrou em relação às intenções integracionistas do peronismo e promoveu a não-resposta como guia para o gerenciamento do vínculo com a Argentina. A diplomacia da obstrução foi uma inflexão na história da política brasileira para aquele país. Seu alcance e escopo não permitiram qualificar o período como de ruptura, uma vez que as regularidades prévias a ela voltaram a permear os princípios de ação defendidos pelo Itamaraty em relação ao Palácio San Martín a partir de meados da década de 1950. A verdadeira ruptura histórica ocorreria anos mais tarde, em meio à redefinição do regime das águas do Prata. É o que se conta a seguir.

\section{A ruptura de uma tendência: a conjuntura crítica}

Entre 1967 e 1973, as relações argentino-brasileiras assistiram a um grau de deterioração raramente visto em sua história. Devido à definição do regime contemporâneo para a utilização do caudal hídrico da Bacia do Prata, o vínculo bilateral foi vítima de um confrontacionismo que se espalhou por ambas as sociedades e terminou turvando os projetos conjuntos de complementação econômica e cooperação técnica que o espírito de Uruguaiana ambicionara. Ao longo desses seis anos, ganhou força uma vertente inédita na diplomacia brasileira contemporânea: a diluição da cordialidade oficial como opção perene nos negócios com o governo argentino.

A iniciativa brasileira de levar adiante o ambicioso projeto hidrelétrico de Itaipu transformou os termos do diálogo internacional na região e fez com que Brasília e Buenos Aires se lançassem à atualização da estrutura do poder do Cone Sul. Nesse quadro, a Argentina buscava garantir regras rígidas que não punissem sua condição de australidade e de país a jusante na quase totalidade de suas fronteiras (há exceções menores na fronteira montanhosa com o Chile) ${ }^{43}$. Já o Brasil ambicionava adotar um corpo jurídico abrangente o bastante para abarcar a sua condição de montante na Bacia do Prata e de jusante na do Amazonas ${ }^{44}$, sem ter com isso que condicionar o seu cronograma de obras à aprovação de Buenos Aires. 
Frustrando a tendência histórica, a primeira atitude do Itamaraty foi a de não buscar fórmulas conciliatórias com Buenos Aires. Até iniciado o governo Geisel, em 1977, a diplomacia brasileira não reconheceu que os temas referentes à construção de Itaipu dissessem respeito à Argentina. Diferentemente, a Argentina, sim, reagiu como se esperava: o Palácio San Martín denunciou com virulência a prática não cooperativa brasileira em todos os foros multilaterais e capitais sulamericanas, acionou suas tradicionais amizades na região e armou-se de instrumentos jurídicos para isolar o Brasil e falsificar-lhe as teses.

Para tanto, a diplomacia argentina ventilou um conceito jurídico vago, mas amplamente aceito em foros internacionais, segundo o qual as construções de obras civis sobre rios internacionais seriam precedidas por uma consulta do Estado empreendedor às partes interessadas, consubstanciando o princípio da consulta prévia. A delegação portenha reclamava ser a consulta prévia a prática defendida pelos países da região desde o decênio de 1930, quando o próprio Brasil tomara a dianteira no assunto ${ }^{45}$. Mais do que isso, lembravam os argentinos que, em 1932, o Brasil e a Grã-Bretanha trocaram notas assegurando que trabalhos sobre as áreas ribeirinhas entre solo brasileiro e a Guiana Inglesa seriam empreendidos com o “consentimento mútuo de ambos" os Estados. O mesmo havia ocorrido, em 1933, no Estatuto Jurídico da Fronteira, assinado por Brasil e Uruguai, dispondo que não se realizariam obras que modificassem o regime e a qualidade das águas de um rio fronteiriço sem o "prévio acordo" do outro Estado ${ }^{46}$.

A força dos argumentos argentinos era ainda mais significativa quando exposta à luz da prática brasileira contemporânea. Em 1960, ao subscrever declaração conjunta referente à construção da represa de Salto Grande sobre o rio Uruguai, Argentina, Brasil e Uruguai comprometiam-se a consultar os demais ribeirinhos caso as obras alterassem o regime do rio, "de acordo com a doutrina e a prática internacional”, a pedido do Brasil ${ }^{47}$. Além disso, a consulta prévia era reconhecida pelo Tratado de Versailles ${ }^{48}$ e pelo Acordo Multilateral sobre o rio Níger ${ }^{49}$.

À época, o homem que representava o Brasil em Buenos Aires não concordava com o rumo que a política externa de seu país estava tomando no tema dos rios. O embaixador Pio Corrêa tinha uma postura clara e definitiva em relação à condução brasileira dos negócios com Buenos Aires. Seu testamento político - última correspondência enviada ao Itamaraty antes de deixar a diplomacia e entrar para a atividade privada, em 1969 - é, ao mesmo tempo, uma carta de orientação para o governo brasileiro e uma adesão aos preceitos da cordialidade oficial que ganham tons de manifesto quando se leva em conta que a mesma foi escrita em um momento de especial tensão entre os dois países. No pensamento de Pio Corrêa, as relações com a Argentina deveriam ser imediatamente restabelecidas em um patamar de "bases (...) cordiais no sentido de uma unificação de pontos-de-vista” ${ }^{50}$. As concepções do embaixador sobre o vínculo bilateral são 
certeiras: havia somente uma política sensata para guiar o relacionamento com a Argentina, qual fosse a da complementação industrial mútua mediante a articulação e o planejamento comum das respectivas políticas de desenvolvimento econômico. A tática que o Itamaraty deveria abraçar era a atuação nas "linhas de menor resistência”, buscando faixas de confluência. A postura brasileira demandaria, segundo ele, "tacto e (...) paciência [sic]"51.

O responsável por explorar uma abordagem alternativa para o desafio argentino foi o sucessor de Pio Corrêa, Antônio Francisco Azeredo da Silveira ${ }^{52}$. Ao chegar a Buenos Aires como embaixador em 1969, Silveira já tinha uma idéia formada da Argentina, de sua política externa e dos desafios que a mesma impunha ao Brasil. Há vários elementos de seu ideário que são relevantes para esta análise: para ele as tensões históricas da sociedade argentina, como a incapacidade de absorver as raças e os povos que compunham a nação, a impossibilitavam de sintetizar um vetor coerente de política externa ${ }^{53}$. Além disso, o país era vítima de uma inversão de expectativas, uma vez que seu "fausto precoce" no cenário latinoamericano cedia lugar em todas as frentes (industrial, comercial, artística, intelectual etc.), e isso o tornava perigoso por incentivar uma política externa revolucionária, isto é, ameaçadora do status quo regional.

O ceticismo de Silveira em relação às possibilidades reais do vínculo Buenos Aires-Brasília entrou em choque com a política do novo mandatário argentino, Lanusse (1971-1973).

A diplomacia argentina passava a concentrar suas energias em negociar declarações que angariassem o apoio dos países sul-americanos à tese da consulta prévia compulsória. Fez isso de forma ostentosa, dando alta densidade política aos encontros e obtendo solidariedades em troca de concessões comerciais. Com Montevidéu, a diplomacia argentina selou o apoio a suas teses mediante o encerramento dos déficits comerciais na balança de pagamentos uruguaia, criando concessões tarifárias unilaterais. Apelando para uma prática pouco comum em documentos dessa natureza, a declaração final trazia um agradecimento do governo uruguaio ao argentino ${ }^{54}$. Mais grave para o Brasil era o documento celebrado entre Argentina e Bolívia, que não somente definia o apoio de La Paz às teses portenhas, mas também garantia a Buenos Aires voz em assuntos amazônicos ${ }^{55}$. A Argentina chegou inclusive a outorgar ao Chile (único país em relação ao qual a Argentina é montante em alguns trechos) a palavra final sobre um dos temas mais pungentes da sua agenda bilateral dos dois países até a década de 1990: a administração das águas de fronteira no complexo geográfico da cordilheira dos Andes. Buenos Aires cedia a Santiago a prerrogativa de definir o regime para o uso das 14 bacias andinas comuns aos dois países em troca de apoio à consulta prévia compulsória.

Silveira apressou-se a indicar a Brasília que os últimos acontecimentos demonstravam que Buenos Aires não estava disposta a negociar nenhum acordo 
efetivo e utilizaria todos os métodos a seu alcance para imputar ao Brasil a responsabilidade pela paralisia das negociações. Para ele, o Itamaraty não deveria compartimentalizar o relacionamento bilateral em diversas áreas (o que, na visão de Pio Corrêa, possibilitaria reduzir a importância das áreas de fricção direta e ressaltar as faixas coincidentes entre os dois países), mas, ao contrário, condicionar todo o relacionamento bilateral à mudança de postura da Argentina. Afirma: "Parece-me (...) que, daqui por diante, qualquer aspecto de nossa política bilateral com a Argentina - desde o intercâmbio comercial até o recurso água, por exemplo - deve ser considerado não apenas em seus aspectos específicos, mas à luz das atuais diretrizes gerais do governo argentino (...) sem pactuar com a presente orientação [do mesmo] ou fazer-lhe concessões (...)" ${ }^{\text {"56 }}$.

O fracasso do projeto eleitoral de Lanusse resultou na posse de Campora - representante de Perón, que se encontrava exilado em Madri - em 25 de maio de 1973, e uma curta trégua entre a Argentina e o Brasil na questão dos rios internacionais. O retorno do embate ocorreria meses mais tarde, com o novo governo de Geisel (1974-1979).

Às vésperas de sua posse, Ernesto Geisel fazia uma avaliação crítica do estado das relações internacionais do Brasil. Para ele, o país tinha condições de arquivar as duas experiências históricas que tradicionalmente impuseram limites estreitos à capacidade brasileira de manobra no exterior: o laço de dependência política dos Estados Unidos e a postura preventiva nos negócios com a Argentina. Nos primeiros meses de 1974, Geisel planejou a reversão desse quadro. Por isso, escolheu para ocupar o Itamaraty um diplomata de carreira com quem rapidamente estabeleceu relações singulares: o próprio Silveira seria o responsável por dar coerência ao projeto internacional do presidente, assim como articulá-lo internamente e resguardá-lo do peso da tradição, que inúmeras vozes ressuscitaram - na imprensa, na caserna e na própria chancelaria - até o fim da gestão em 1979. Os primeiros discursos oficiais sinalizavam claramente que haveria uma redefinição de prioridades no perfil internacional do país, sem, contudo, oferecer detalhes concretos $^{57}$.

Coube ao presidente cunhar e anunciar o título - costume comum à época - da nova orientação externa brasileira, o Pragmatismo Responsável ${ }^{58}$. Sinteticamente, é possível sugerir que esse paradigma consistiu na exploração de oportunidades que emanavam da flexibilização do confronto Leste-Oeste. Na prática, isso significava: as vantagens de negociar com uma Europa fortalecida e crescentemente autônoma em relação aos desígnios norte-americanos; a possibilidade factível de negociar acordos com regimes marxistas, o apoio às independências africanas e à causa palestina; e a busca da cooperação horizontal com outras potências regionais, principalmente no campo energético e científicotecnológico. A orientação externa do governo Geisel representou o desenvolvimento do paradigma externo acumulado com mais ou menos intensidade desde Vargas, 
qual seja a instrumentalização da diplomacia em busca de insumos para o projeto nacional-desenvolvimentista ${ }^{59}$.

A questão dos rios ocupou o novo governo desde o primeiro dia, como pode ser visto pela cerimônia de posse de Geisel. Lá estavam presentes Hugo Banzer, da Bolívia; Augusto Pinochet, do Chile ${ }^{60}$; e Juan Maria Bordaberry, do Uruguai $^{61}$. A presença de Perón, que havia sido cogitada, não vingou, sugerindo que ambas as chancelarias tinham uma pendência, qual fosse a questão de Itaipu, naquele momento não reconhecida pelo governo brasileiro como tal ${ }^{62}$.

Agravando o clima das relações bilaterais, em março de 1976, as Forças Armadas argentinas depuseram Isabel Perón e deram início a um programa de intervenção militar por elas batizado de Processo de Reorganização Nacional. O fenômeno atingiu diretamente a diplomacia argentina. No dia mesmo do golpe, o Palácio San Martín foi fisicamente ocupado por tropas da Marinha, e poucos diplomatas puderam aceder a seus postos de trabalho, sendo que as principais chefias e departamentos foram confiados a militares daquela Força. A resultante internacional do regime militar argentino inaugurou padrões inéditos na vida do país. Pela primeira vez, a política econômica abandonava a industrialização como instrumento de inserção na economia internacional (entre 1976 e 1983, a produção industrial argentina caiu 20\%), e o governo que assumira o comando para abrir o mercado nacional ao comércio exterior terminou por fechá-lo ainda mais ${ }^{63}$. Pela primeira vez na história, o país chegou por duas vezes à iminência de guerra contra o Chile e perdeu uma guerra convencional contra um poder da Organização do Tratado do Atlântico Norte (OTAN).

Também pela primeira vez a diplomacia argentina foi articulada de forma a construir um projeto de presença regional calcado na tese das "fronteiras ideológicas”, segundo a qual o papel da política externa argentina era combater o comunismo nas Américas. Dessa forma, Videla repetia o modelo de relações externas de Castelo Branco ${ }^{64}$, e o adensava. Paradoxalmente, e evidenciando mais uma das profundas contradições que marcaram o período, a estratégia do regime não impediu Buenos Aires de apoiar Cuba e Líbia em foros regionais e globais, estreitar relações com a Alemanha Oriental, Coréia do Norte e Vietnã do Norte, ou mesmo aumentar a participação da União Soviética para 30\% em sua balança comercial ${ }^{65}$.

Também foi a primeira vez em que a agenda externa foi moldada sobre as premissas tradicionais do nacionalismo territorial argentino ${ }^{66}$, qual seja a de que as fronteiras do país foram vilipendiadas pela Coroa espanhola, pelos vizinhos e por poderes extracontinentais desde tempos imemoráveis. Dessa forma, o desafio internacional argentino era percebido em 1978 em sete frentes de "preservação da soberania”: as ilhotas do Canal de Beagle, reclamadas também pelo Chile; a definição da quantidade das águas do Alto Paraná, tomada pelo Brasil como tema de exclusiva soberania brasileira; a bandeira das Ilhas Malvinas, em posse do 
Reino Unido desde o século XVIII; a projeção continental argentina sobre a Antártida, linhas postas em xeque por Chile, Uruguai e Reino Unido; fronteiras andinas, trechos montanhosos reclamados pelo Chile; e o traçado do mar continental argentino, questionado por Brasil, Chile, Uruguai e Reino Unido ${ }^{67}$.

Quando a ditadura militar chegou ao fim, em 1983, a Argentina, que durante grande parte do século XX ocupara um lugar privilegiado na estrutura regional de poder, chegava à democracia em um isolamento raramente experimentado. Dias antes do golpe, o The Buenos Aires Herald publicava editorial denunciando que a diplomacia portenha havia-se deixado ultrapassar pela Venezuela, que agora ocupava a tríade latino-americana com Brasil e México. Diferentemente dos três grandes, a Argentina não tinha nada a oferecer para seus tradicionais parceiros, nem mesmo para seus vizinhos ${ }^{68}$.

Em meados de 1976, o presidente Videla indicou Oscar Camilión para ocupar a embaixada em Brasília com um projeto diplomático ambicioso ${ }^{69}$. Do ponto de vista das posições domésticas, deveria mostrar à opinião pública de seu país que era possível negociar com o Brasil retirando a carga negativa que a imprensa portenha imputava a tudo o que estivesse relacionado com a política externa brasileira, assim como apaziguar os ânimos que alimentavam certos setores militares ${ }^{70}$. Em relação ao Itamaraty, o principal objetivo de Camilión era convencer o governo brasileiro de que o aproveitamento do rio Paraná era um assunto que devia ser negociado com a Argentina sob pena da iniciativa não contar com legitimidade internacional.

A agenda do embaixador argentino não deixa de assemelhar-se, do ponto de vista lógico, àquela advogada por ele mesmo havia quinze anos, no contexto dos acordos de Uruguaiana ${ }^{71}$. A proposta incluía a noção de que Buenos Aires e Brasília deveriam estabelecer sistema de coordenação de posições nos foros internacionais, trocar informações sensíveis e promover a sistemática prática da consulta bilateral para assuntos de interesse mútuo ${ }^{72}$. Silveira desconfiava que, ao retomar os princípios de Urugaiana, Camilión estivesse à procura de uma justificativa teórica para a tese da "consulta prévia”. O chanceler brasileiro deve ter entendido que o perigo da gestão de Camilión residia justamente em promover uma associação entre a "consulta diplomática" - mecanismo bastante usual entre Estados - e a “consulta prévia compulsória”, cujo caráter é suspensivo.

O estilo de Camilión contrapunha-se frontalmente aos modos simples do chanceler Silveira. Esse diferencial tinha bases intelectuais. Para o chanceler, o segredo e a reserva eram a essência da atividade diplomática ${ }^{73}$. Sua percepção traduzia-se em certo desconforto diante da imprensa, pois as dinâmicas negociadoras eram justamente calcadas naqueles dados que não eram notícia ${ }^{74}$. A política publicista de Camilión chegou a provocar o próprio Geisel, que em discurso no Clube Naval ao corpo diplomático sediado em Brasília, em 10 de maio de 1977, afirmava: "Não sou dos que acreditam que a diplomacia tradicional tenha sido 
superada pela eficiência dos modernos meios de comunicação. Ao contrário, creio que a própria eficiência desses meios pode iludir-nos, levando-nos a confundir publicidade com negociações ${ }^{75}$ ".

Sob a influência de fenômenos assim, Silveira procurou adaptar a diplomacia aos novos padrões de relacionamento com a opinião pública. Articulou a sua assessoria de comunicação sob a chefia do então ministro, e mais tarde chanceler, Luiz Felipe Lampreia. A documentação primária revela que se preocupou também, de forma sistemática, em acertar as suas declarações públicas previamente com os parceiros da negociação e dedicou atenção pessoal à elaboração de press releases sobre as negociações de Itaipu.

Nesse contexto, o Brasil lançou uma aposta regional sem precedentes, ao propor a celebração de um ambicioso pacto político na América do Sul sem a anuência ou a participação da Argentina - o Tratado de Cooperação Amazônica (TCA). A formulação do mesmo ocorreu na chancelaria brasileira atendendo à lógica, dentre outras, de que era chegada a hora de consagrar a doutrina brasileira para os rios internacionais em toda a América do Sul e afiançar os laços de amizade com as fronteiras setentrionais do país no intuito de fortalecer as posições de Brasília vis-à-vis Buenos Aires. A novidade introduzida pelo TCA era a dimensão política do gesto brasileiro de convidar todos os países setentrionais da América do Sul a assinar, em Brasília, um instrumento de convergência regional em uma região em que todos os países - com exceção do Brasil - tinham questões limítrofes pendentes ou haviam sofrido efetivas perdas territoriais para seus vizinhos ${ }^{76}$. Em quinze meses, Silveira havia conseguido transpor as objeções de Venezuela, Guiana, Suriname, Colômbia, Equador, Peru e Bolívia.

Diferentemente da época da cordialidade oficial, quando a Argentina era sistematicamente incluída nos projetos internacionais do Itamaraty, a grande iniciativa do governo Geisel na América do Sul foi estruturada sob o princípio da contenção política da Argentina na região. A estratégia sul-americana de Silveira incluiu ainda acordos com Bolívia e Uruguai, cuja tônica era trocar vantagens políticas por incentivos econômicos ${ }^{77}$. É de então que datam a declaração brasileira de apoio às demandas bolivianas por uma saída para o mar e a assinatura de Tratado da Lagoa Mirim com o Uruguai, importante sinalização da postura conciliadora do Brasil no tratamento de bens públicos internacionais como a água ${ }^{78}$.

No eixo dos relacionamentos assimétricos, o Secretário Henry Kissinger compartilhava o ceticismo de Silveira em relação à política externa argentina. Se, por um lado, o estadista norte-americano não visitou o país austral deliberadamente, por outro, o chanceler brasileiro descartou a possibilidade da promoção do diálogo entre o Departamento de Estado e o Palácio San Martín. Já com o Presidente Jimmy Carter (1977-1981), cujo pensamento internacionalista opunha-se frontalmente ao de Kissinger, as crescentemente deterioradas relações brasileiro- 
estadunidenses não abriram sequer espaço para uma eventual aproximação entre Buenos Aires e Washington que fosse promovida pelo Itamaraty. Se, à época da cordialidade oficial, a "aliança não escrita” entre o Brasil e os Estados Unidos servia como alavanca do vínculo brasileiro-argentino, durante a conjuntura crítica da década de 1970 esse padrão foi abertamente descartado.

Vale notar que a paralisia das instâncias diplomáticas na promoção de avanços sensíveis acionou as corporações militares. Há indícios de que tanto o SNI quanto o Centro de Informações e Segurança do Exército enviaram expedições à Argentina em 1977 para preparar relatórios sobre a questão dos rios internacionais ${ }^{79}$. Entre abril de 1976 e julho de 1977, militares de primeiro escalão dos dois países dialogaram em visitas sigilosas a Buenos Aires e ao Rio de Janeiro para tratar do tema ${ }^{80}$. Emílio Massera chegou a afirmar publicamente: "Devemos estar prontos para corrigir desvios, advertir erros e evitar astúcias supérfluas que nos afastem dos objetivos transcendentes que unem o Brasil e a Argentina ${ }^{81}$ [minha tradução]”.

Os encontros parecem ter surtido efeito nas chancelarias porque dias depois dos últimos encontros as diplomacias voltavam a sentar-se à mesa de negociações sob a condição de que a Argentina observaria irrestritamente o Tratado de Livre Navegação assinado entre Argentina e Brasil em $1857^{82}$, recentemente questionado por Videla.

O elemento que deflagrou drasticamente os tempos da negociação, no entanto, foi uma declaração do embaixador argentino sobre suas percepções em relação ao programa nuclear brasileiro, afirmando que o mesmo se tratava de iniciativa pacífica e que não somente não constituía nenhuma ameaça para a Argentina como abria uma possibilidade ímpar para pensar, em ambos os países, a coordenação das políticas nucleares de Argentina e Brasil em prol do desenvolvimento do Cone $\mathrm{Sul}^{83}$. No Brasil, o depoimento suscitou reações radicais em nível governamental, quase chegando a valer ao embaixador a declaração de persona non grata ${ }^{84}$. Até mesmo Buenos Aires quase demitiu seu embaixador, pois os militares argentinos pretendiam que a Argentina fosse o país latino-americano a ter o monopólio nuclear da região e, segundo Camilión, não viam com bons olhos a associação ao Brasil nesse campo. Mas não foi assim com a opinião pública.

A imprensa brasileira recebeu o depoimento positivamente, por entender que o apoio argentino ao projeto nuclear brasileiro era uma credencial a mais para fazer frente ao "imperialismo ianque”. O próprio embaixador Nogueira Batista, que presidia a Nucleobrás, estava convencido da necessidade de cooperação com a Argentina para fazer frente à pressão norte-americana ${ }^{85}$. Contudo, a vitória de Camilión no Brasil foi temperada por seu fracasso inicial junto à opinião pública argentina e a setores de seu próprio governo. A imprensa local acusava-o de ceder com facilidade aos "pequenos gestos de Silveira”, sua estratégia era 
denunciada “concessória”, e seus poderes, “excessivos”86. Assim como nos tempos de Frondizi e Quadros nos anos sessenta, quando tivera alguma responsabilidade pelo espírito de Uruguaiana, o Camilión dos setentas enfrentou setores da opinião pública argentina abertamente hostis à idéia de concertar posições com o Itamaraty ${ }^{87}$.

Os acertos técnicos para a assinatura de um entendimento entre Buenos Aires e Brasília estavam praticamente definidos em outubro de 1978. Nunca o entendimento havia estado tão próximo. Em conversa telefônica no dia 24 daquele mês, os dois chanceleres dispunham-se a celebrar algum tipo de acordo que encerrasse o desentendimento. $\mathrm{O}$ mesmo cumpria inteiramente as demandas brasileiras $^{88}$. Faltava apenas definir a forma jurídica que o documento final teria. Durante a X Reunião de Chanceleres da Bacia do Prata (Punta del Este, dezembro de 1978), Silveira sugeriu à contraparte argentina a "trilateralização" das notas reversais trocadas com o Paraguai, como forma de fugir à fórmula de um acordo e consagrar um entendimento eminentemente técnico. A delegação argentina não aceitou a proposta ${ }^{89}$ e, alternativamente, enviou ao Brasil um emissário com amplos poderes com a intenção de renegociar parâmetros previamente definidos. Geisel e Silveira decidiram encerrar definitivamente as conversas com os argentinos, deixando um eventual entendimento para o próximo governo, que assumiria meses depois.

Em 30 de janeiro de 1979, a diplomacia argentina jogava mais uma vez com as conjunturas políticas de Brasília. Apesar de saber que o governo de Geisel resumira as negociações, Buenos Aires aumentou o dissonância com o Itamaraty ao sugerir publicamente uma nova rodada de negociações. Essa atitude, pela qual a Argentina aproveitava o fim do mandato de Geisel para dar a entender à opinião pública que a falta de avanços devia-se à postura arrogante do governo brasileiro, irritou Silveira profundamente. Seus gestos de frieza em relação à delegação argentina, durante o último encontro tripartite de sua gestão (Assunção, Janeiro de 1979), fizeram-no passar para a história com a pecha de "carnavalesco”, "perigoso", "pouco sério", "inconsciente” e "pueril” em editoriais de Jornal do Brasil, O Estado de S. Paulo e Folha de S. Paulo do dia $1^{\circ}$ de fevereiro de 1979.

Conclui-se que o governo Geisel desenvolveu uma política intolerante ao perfil denuncista da diplomacia argentina, respondendo frontalmente a suas acusações; não buscou faixas de coincidência para diluir o clima de contencioso em torno à questão dos rios internacionais e, embora o comércio bilateral desse um significativo salto durante o período, sujeitou todas as áreas da relação bilateral à dinâmica da negociação do regime fluvial da Bacia do Prata; excluiu a Argentina das iniciativas multilaterais de Brasília, isolando Buenos Aires por meio de um renovado sistema de projetos regionais; e, finalmente, não utilizou o canal privilegiado de comunicação com a Washington de Henry Kissinger ${ }^{90}$ para reduzir os atritos entre a Argentina e os Estados Unidos, nem buscou associar-se à Junta da Casa Rosada para dialogar com Jimmy Carter ${ }^{91}$. 


\section{O projeto de integração: o legado}

O início do governo Figueiredo, em 1979, criou as condições para a reforma geral da política brasileira em relação à Argentina: era necessário definir um lugar para o vizinho mais importante nas prioridades diplomáticas do país depois do fiasco que constituíra a demorada negociação dos rios internacionais. A restauração do relacionamento bilateral em um novo ponto de equilíbrio aceitável a ambas as nações demandou um programa intenso de cooperação que se estendeu ao longo de toda a década de 1980. É nesse período que a diplomacia brasileira abriu o caminho para a cooperação bilateral em matéria militar, nuclear e comercial, mecanismos que prepararam as bases para um ambicioso projeto cooperativo.

A natureza e o escopo da parceria estratégica que então nascia com o vizinho, entretanto, eram substancialmente diferentes daquelas presentes durante os anos da cordialidade oficial. Com efeito, tratava-se de um novo paradigma de relacionamento com Buenos Aires, originado diretamente da conjuntura crítica que marcou o cálculo estratégico brasileiro para aquele país desde o governo de Médici. A partir do novo padrão inaugurado por Figueiredo, em 1979, estavam dadas as bases materiais para o projeto de integração.

O mesmo era alternativa concreta para a voraz reação norte-americana aos planos autônomos de desenvolvimento energético, os escassos resultados palpáveis da opção européia ${ }^{92}$ e a construção de um sistema de comércio no Cone Sul instrumental aos interesses brasileiros. A parceria com a Argentina começava a configurar-se como uma contingência praticamente inevitável, caso o Brasil pretendesse manter a sua ascendência política no campo das relações internacionais. Portanto, a convergência da política externa brasileira com a argentina, ao princípio dos anos oitenta, é substancialmente diferente daquela ocorrida, por exemplo, em 1961, no marco dos acordos de Uruguaiana.

A intensidade outorgada pelo novo mandatário brasileiro à aproximação com a Argentina constituiu o primeiro mecanismo a dar origem a esse projeto. $\mathrm{O}$ perfil personalista das viagens presidenciais ${ }^{93}$ inaugurava uma era há tempos reclamada pela imprensa brasileira e necessária para marcar uma ruptura clara com o passado recente, gestando assim uma atitude pró-ativa em todos os níveis do eixo Brasília-Buenos Aires. Devido ao fato de que visitas em nível de chefe de Estado raramente são ocasiões de negociação, e sim gestos que confirmam ou reafirmam linhas gerais de ação diplomática, as visitas de Figueiredo revelam o comprometimento brasileiro com uma nova postura.

Essa orientação deu vida ao segundo mecanismo, qual fosse a manutenção de relações íntimas em que pesasse a discórdia ideológica dos dois regimes militares em temas sensíveis como o golpe de Estado na Bolívia, em 1980, e a política norteamericana para a América Central. No entanto, a quantidade dos instrumentos assinados naquelas ocasiões, assim como o compromisso político e pessoal do 
presidente com os argentinos, não atravessou o período sem testes significativos. As pressões norte-americanas no tema da proliferação nuclear e a malfadada invasão argentina às Malvinas puseram o Brasil face a constrangimentos definidores de sua atuação externa.

Com Figueiredo, não se tratava de tolerar o discurso argentino, de buscar áreas pouco conflitivas para a aproximação de ambas as chancelarias, de incluir a Argentina em grandes projetos de Brasília e muito menos de promover bons ofícios entre o Palácio San Martín e o Departamento de Estado norte-americano. A questão não era precaver-se dos avanços diplomáticos argentinos e sim outorgar àquele país, paulatinamente, um lugar preponderante na estratégia internacional do Brasil.

O marco de referência que, no decênio de 1970, advogava relações especiais com o mundo desenvolvido como instrumento de redenção do país na cena internacional cedeu passo à formulação de uma parceria simétrica com a Argentina, refletida nos protocolos bilaterais de 1986 (Ata para a Integração Argentino-Brasileira) e no Tratado de Integração, Cooperação e Desenvolvimento de 1988. Nascia o princípio segundo o qual Argentina e Brasil deveriam integrar certas unidades produtivas com a finalidade de promover tecnologias sensíveis em setores estratégicos para o desenvolvimento econômico.

Mais do que isso, a aproximação entre as duas novas democracias do Cone Sul constituía uma verdadeira corrida em busca de credenciais democráticas que permitissem a ambos os países encerrar o seu isolamento em importantes praças diplomáticas e foros multilaterais devido às vergonhosas situações internas dos direitos humanos. Os dois governos apressaram-se a aceder ao regime interamericano de proteção aos direitos humanos, assim como aos pactos e convenções de consenso sob a égide das Nações Unidas.

Dessa forma, procedia a diplomacia brasileira a estabelecer uma relação privilegiada no contexto do universalismo alcançado ao longo das últimas décadas. A qualificação do relacionamento com a Argentina ocorreu, portanto, no marco das parcerias estratégicas, qual seja (a) a perseguição dos elementos cruciais que o aparelho de Estado define como desenvolvimento econômico (mercados, tecnologias, fontes de energia), (b) a promoção da concertação internacional nos fóruns multilaterais, (c) a articulação de uma alternativa factível às tradicionais "relações especiais" com os Estados Unidos, (d) o aumento significativo dos fluxos econômicos, e (e) a consecução de presença internacional própria ${ }^{94}$.

Vê-se que o projeto de integração com a Argentina não retoma os princípios da cordialidade oficial, isto é, a tolerância com o discurso do outro, a busca de faixas de convergência para esquivar a discórdia frontal, a inclusão do outro nas iniciativas da chancelaria e a promoção dos bons ofícios com Washington. Tratase, efetivamente, de uma estratégia alternativa para lidar com o desafio que a Argentina representa para a diplomacia brasileira. 
O fracasso do liberalismo aplicado à Argentina ${ }^{95}$, fonte de convulsões sociais e políticas sem precedentes, que ocorre paralelamente ao fim do segundo mandato de Fernando Henrique Cardoso, sugere que a capacidade de sobreviver às lideranças é apenas um dos muitos testes de resistência aos quais o projeto de integração será confrontado nos primeiros anos do século XXI. Trata-se, em outras palavras, de responder às difíceis perguntas que assolam todo vínculo dessa natureza: qual é o grau de unidade que se espera do comportamento externo de cada um, quais os níveis de desentendimento que são toleráveis por ambas as partes, e qual o espaço que cada um tem para atuar independentemente?

Em quase duas décadas de vida, o projeto de integração regional atualizou as agendas externas de Argentina e Brasil tão eficientemente que ambos os países o utilizam como credencial internacional mais importante. Essa parceria contribuiu significativamente para: democratizar e pacificar o subcontinente, multiplicar os fluxos de comércio bilateral e fazer da América do Sul um ator minimamente notado nas relações internacionais contemporâneas.

\section{Conclusão}

Neste artigo sugeriu-se que, no contexto prático do embate pela utilização dos recursos hídricos da Bacia do Prata, a diplomacia de Geisel desestruturou o ideário tradicional da política brasileira para a Argentina. Por sua vez, a dramaticidade desse fenômeno terminou por criar o ambiente necessário para a redefinição do lugar daquele país no marco das relações internacionais do Brasil, objetivo articulado por Figueiredo e defendido com maior ou menor sucesso por todos os governos desde então.

Em princípios do século XX, o Barão do Rio Branco tomou para si a tarefa de estruturar uma orientação preventiva em relação à Argentina. Oito decênios mais tarde, a diplomacia brasileira redefinia o vínculo bilateral à luz de uma fórmula de concerto inusitada. O responsável por criar as condições para que essa mudança ocorresse foi Ernesto Geisel, pois durante seu governo os princípios e conceitos tradicionalmente utilizados para lidar com o desafio argentino colapsaram.

Encerrada a negociação sobre Itaipu, a diplomacia brasileira estava em condições de reavaliar o lugar do vizinho em seu marco conceitual. Assim, buscouse uma agenda capaz de refletir os interesses paralelos que ambas as nações tinham naquela conjuntura e outorgou-se fôlego ao programa de convergência em assuntos de defesa e política internacional. Se, ao longo do século XX, a política externa brasileira foi guiada pela necessidade imperiosa de evitar que o vizinho único poder sul-americano capaz de ombrear o Brasil em oportunidades e responsabilidades no cenário regional e internacional - lhe turvasse os horizontes, depois de Itaipu a prevenção como método brasileiro de administração havia caducado. Não havia mais motivos de angústia para a atuação diplomática brasileira 
na América do Sul, mas a Argentina, por seu vulto, ainda demandava algum tipo de postura. A integração regional foi a resposta.

Além de oferecer indícios para uma interpretação alternativa das relações argentino-brasileiras ao longo do século XX, este trabalho revelou que a mudança de estratégia de um país na cena internacional não apenas é causada por fatores estruturais, mas também pode ser precipitada pelo esforço de suas lideranças.

\section{Notas}

1 Princípios são regras, leis e proposições cujas verdades não são questionadas. Concepções são as maneiras utilizadas para formular idéias, projetos ou planos. PRINCÍPIO e CONCEPÇÃO. In: Novo Dicionário Aurélio. 3. ed. Nova Fronteira: 1998. p.1639 e 519, respectivamente. HILTON, Stanley. Brasil-Argentina: história de um encontro. Revista Brasileira de Política Internacional, a. 23, no 89-92, p. 101-118, 1980.

3 Depoimento, cassete $n^{\circ}$ 6, lado B, 18 maio 1979.

4 A categoria foi desenvolvida por COLLIER, David \& COLLIER, Ruth. Shaping the political arena: critical junctures, the labor movement, and regime dynamics in Latin America. Princeton, N.J.: Princeton University Press, 1991. Trata-se de estudo comparado entre oito países latinoamericanos, que visa a definir qual o impacto da incorporação das classes urbanas à vida pública dessas sociedades. Conclui-se que, ao longo dos respectivos períodos de incorporação, houve mudanças significativas nos sistemas produtivo e político, assim como relações sociais. Dessa forma, os autores argumentam que a inclusão dessa nova classe constituiu uma conjuntura crítica na história desses países, uma vez que fez toda a diferença na evolução posterior dos mesmos.

5 RENOUVIN, Pierre; DUROSELLE, Jean-Baptiste. Introdução à História das Relações Internacionais. São Paulo: Difel, 1967. p. 407-434. Essa categoria é denominada, na politologia, liderança política.

6 Ibid., p. 480.

7 Em 1821, D. João anexou a Província Cisplatina, incorporando-a em seguida ao Império brasileiro. Três anos mais tarde, contudo, uma declaração de independência uruguaia inaugurou um período de instabilidade regional que levou Buenos Aires a incorporar a Cisplatina. O imperador D. Pedro, por sua vez, reagiu com uma guerra e um bloqueio naval contra a capital portenha. $\mathrm{O}$ resultado das negociações entre as diplomacias de Buenos Aires e Rio de Janeiro, sob mediação inglesa, foi a criação do Estado uruguaio e a garantia da liberdade de navegação no Prata, em 1828. CERVO, A.mado; BUENO, Clodoaldo. A política externa brasileira (1822-1985). São Paulo: Ática, 1986. p. 36-37.

8 Em meados do século XIX, a diplomacia brasileira no Prata enfrentava o desafio imposto pelo caudilho argentino Juan Manuel de Rosas, que punha em questão a independência do Uruguai de 1828, a do Paraguai, a liberdade de navegação no Prata, as fronteiras sulinas do Brasil e, ainda, era percebido por certas vozes do parlamento imperial como um homem à procura da restituição a Buenos Aires das fronteiras originais do Vice-Reinado do Prata (englobando Bolívia, Paraguai e Uruguai). A resposta brasileira ocorreu mediante uma complexa associação de táticas para eliminar Rosas: alianças com os países do Pacífico e da Bacia do Prata (inclusive as províncias de Corrientes e Entre Rios), a diplomacia familiar de D. Pedro para assegurar a neutralidade inglesa no assunto, a força das finanças do Barão de Mauá e as armas. Isso, somado às inamizades que Rosas cultivara nas províncias argentinas, terminou por levá-lo ao exílio em 1852. CERVO, Amado; BUENO, Clodoaldo. História da política exterior do Brasil. São Paulo: Atica, 1992, p. 98-104. 
$9 \quad$ No início da década de 1860, o Paraguai ressentia-se de haver perdido, paulatinamente, a capacidade de mobilização do sistema subregional. A sua estratégia, porém, continuava a mesma de outrora, que consistia na promoção de um equilíbrio de forças que preservasse os pequenos (Paraguai e Uruguai) da intervenção dos grandes (Argentina e Brasil). Na prática, isso significava a eventual criação de um Estado que reunisse Uruguai, Paraguai, Corrientes, Entre Rios e, quiçá, as missões rio-grandenses. A instabilidade que se seguiu resultou na intervenção brasileira no Uruguai que, por sua vez, levou o Paraguai a invadir territórios argentinos e brasileiros. Nessas circunstâncias, o Império financiou com recursos de seu Tesouro e de empréstimos ingleses a longa Guerra do Paraguai ou da Tríplice Aliança (1865-1870), auxiliando inclusive o argentino Mitre com empréstimos de vulto. CERVO; BUENO. História..., p.107-112.

10 BANDEIRA., Moniz. As relações regionais no Cone Sul: iniciativas de integração. In: CERVO, Amado; RAPOPORT, Mario (Orgs.). História do Cone Sul. Rio de Janeiro e Brasília: Renavan e Universidade de Brasília, 1998, p. 292-295.

11 PARADISO, J. Debates y trayectoria de la política exterior argentina. Buenos Aires: Grupo Editor Latinoamericano, 1993. p. 17-61.

12 Para uma síntese de como o Prata constituiu um “laboratório da inteligência nacional”, ver CERVO, Amado L. Intervenção e neutralidade: doutrinas brasileiras para o Prata nos meados do século XIX. Revista Brasileira de Política Internacional, a. 26, n.101-104, p. 101-114, 1983.

13 Ministro dos Negócios Estrangeiros entre 1855-1857, 1858-1859 e 1868-1871. De 1871 a 1875, comandou o “Gabinete Rio Branco” (presidente do Conselho de Ministros). Ver HIRST, M. A diplomacia brasileira. Disponível em <http://www.mre.gov.br/acs/diplomacia/portg/ arquivo/crob001.htm>.

14 CERVO. Intervenção..., p. 116.

15 BANDEIRA. As relações regionais... p. 216-217.

16 DORATIOTO, Francisco M. A política platina do Barão de Rio Branco. Revista Brasileira de Política Internacional, a.43, nº 2, 2000, p. 133.

17 CONDURU, Guilherme. O subsistema americano, Rio Branco e o ABC. Revista Brasileira de Política Internacional, a.42, $\mathrm{n}^{\circ}$ 2, 1998, p. 63.

18 Em 1902, a Venezuela, que havia cessado o pagamento de sua dívida pública, enfrentou o bloqueio de suas costas, a apreensão de sua frota marítima e o bombardeio de um de seus portos por Inglaterra, Alemanha e Itália, com o consentimento expresso dos Estados Unidos. A Argentina, por meio de seu chanceler Luís María Drago, condenou a postura da Casa Branca por entender que o emprego da força para a cobrança de dívidas era ilegítimo. Na América do Sul, a condenação veemente da Argentina não mobilizou o Rio de Janeiro, que preferiu um "silêncio oficial”. Para interpretações sobre este tema ver CERVO; BUENO. História..., p. 173-176 e PARADISO, José. Debates y trayectoria de la política exterior argentina. Buenos Aires: Grupo Editor Latinoamericano, 1993, p. 50.

19 A Doutrina Monroe é o fundamento da diplomacia dos Estados Unidos oriundo da mensagem do presidente James Monroe ao Congresso em dezembro de 1823, advogando três pontos: a) não se permitiria nenhum novo intento de colonização européia no Novo Mundo; b) os Estados Unidos se absteriam dos assuntos referentes à Europa e, em contrapartida, c) a Europa não interviria nos governos do hemisfério ocidental. O corolário que dela emana resultou de uma série de declarações do presidente Theodore Roosevelt (1901-1909) entre 1901 e 1902, quando o mesmo afirmava que os Estados Unidos desempenhariam função de polícia na América Latina no intuito de garantir que essas nações cumprissem suas obrigações internacionais. MONROE DOCTRINE. In: ENCYCLOPEDIA Brittannica (Micropedia). 15. ed. Chicago: University of Chicago, 1978. vol. VI. p. 1007 e THEODORE ROOSEVELT. In: ENCYCLOPEDIA Brittannica (Macropedia). 15. ed. Chicago: University of Chicago, 1978. vol. XV. p. 1143. 
20 Respondendo ao lema de “América para os Americanos”, Saenz Peña (Presidente entre 1910 e 1914) propunha a "América para a Humanidade”, calcada na idéia de que "nenhum estado americano tem direto a falar em nome de um hemisfério”. BANDEIRA, Moniz. O eixo Argentina-Brasil: o processo de integração da América Latina. Brasília: Universidade de Brasília, 198, p. 19.

21 BURNS, E. The unwritten alliance: Rio Branco and Brazilian-American relations. New York: Columbia University Press, 1966. p. 175.

22 CERVO. Relações internacionais..., p. 102-103.

23 Ver PUIG, Juan Carlos. Política internacional argentina. In: PERINA, R. M. e RUSSEL, R. (Orgs.). Argentina en el mundo, 1973-1987. Buenos Aires: Grupo Editor Latinoamericano, 1988. p. 11-45.

24 DORATIOTO, Francisco. As políticas da Argentina e do Brasil em relação à disputa bolivianoparaguaia pelo Chaco, 1926-1936. In: FUNDAÇÂO ALEXANDRE DE GUSMÂO. A visão do outro: seminário Brasil-Argentina. Brasília: FUNAG, 2000, p. 446-458

25 O presidente Justo visitou o Rio de Janeiro em 1933 para assinar o Pacto Saavedra-Lamas. Vargas, por sua vez, foi a Buenos Aires em 1935 por ocasião da Conferência de Paz do Chaco. Ver FRAGA, Rosendo. Los Acuerdos Vargas-Justo, 1933-1935. In: FUNDAÇÃO ALEXANDRE DE GUSMÃO. Op. Cit., p. 401-422.

Presidente argentino entre 1946-1951, 1951-1955 e 1973-1976.

27 CERVO, Amado. Relações internacionais da América Latina: velhos e novos paradigmas. Brasília: FUNAG e IBRI, 2001. p. 211-228.

28 CERVO. Relações internacionais..., p. 160-161.

29 LANÚS, Archibaldo. De Chapultepec al Beagle: política exterior argentina, 1945-1980. 2.ed. Buenos Aires: Emecé, 2000, p. 313.

30 BANDEIRA., Moniz. Estado nacional e política internacional na América Latina: o continente nas relações Argentina-Brasil, 1930-1992. e. Ed. Brasília: Universidade de Brasília e Ensaio, 1995, p. 93.

31 MOURA, Gerson. A segurança coletiva continental: o sistema interamericano, o TIAR e a Guerra Fria. In: ALBUQUERQUE, J. A. G. (Org). Sessenta anos de política externa brasileira, 1930-1990: crescimento, modernização e política externa. São Paulo: Editora Vox, 1996. v. 1. p. 163.

32 HILTON. The argentine factor in XX century: Brazilian foreign policy strategy. Political Science Quarterly. V. 100, n.1, spring 1985, p. 38.

33 LANÚS. Op. Cit., p. 22-23.

34 PUIG. Politica internacional..., p. 27.

35 CERVO, Amado L. (Org.). O desafio internacional. Brasília: Universidade de Brasília, 1994. p. 40.

36 Espírito de Uruguaiana foi o nome dado ao conjunto de acordos assinados por Jânio Quadros e Arturo Frondizi, discriminados a seguir: Convênio de Amizade e Consulta; Declaração Presidencial Conjunta; Declaração Econômica; e Declaração sobre Intercâmbio Cultural, celebrados na cidade fronteiriça de Uruguaiana (Rio Grande do Sul) entre 20 e 22 de abril de 1961. A esses documentos, somam-se a Declaração Conjunta, o Tratado de Extradição e a Convenção sobre Assistência Judiciária Gratuita que o chanceler San Tiago Dantas assinou com seu par argentino, Miguel Cárcano, em novembro do mesmo ano, em Buenos Aires.

37 A tese sobre a multilateralização da política externa brasileira durante o regime militar (19641985) é defendida por VIZENTINI, Paulo Fagundes. A política externa do regime militar brasileiro. Porto Alegre: Universidade Federal do Rio Grande do Sul, 1998.

38 Ainda nos primeiros anos do governo Castelo Branco, o Itamaraty propôs complementação industrial e colaboração no desenvolvimento da Bacia do Amazonas a Colômbia, Equador e 
Peru, ensaiando a procura da liderança mediante a exploração de elementos de aproximação que marcariam a política brasileira para seus vizinhos sul-americanos na década de 1970.

CERVO. Relações internacionais... p. 211-235 e 241-243.

40 Cf. Cit.; COSTA, Op. Cit.; BANDEIRA, As relações regionais...

41 BANDEIRA. Estado nacional..., p. 191.

\section{BANDEIRA. As relações regionais..., p.324}

43 A Argentina defendia acertos multilaterais rígidos para garantir que: a) não fossem causados prejuízos ao Estado a jusante com as obras de engenharia sobre rios internacionais; b) os Estados interessados fossem previamente consultados sobre os projetos de engenharia sobre rios internacionais; c) “Estado interessado" fosse considerado toda unidade soberana que pudesse ser afetada pela execução de trabalhos em rios internacionais. LANÚS. Op. Cit., 297-317.

Em 1965, o Parecer do Consultor Jurídico do Itamaraty esboçava uma orientação geral sobre o tema. Recomendava ao governo brasileiro que: a) o regime regulador das águas internacionais deveria limitar-se a definir princípios gerais sobre os quais as partes pudessem negociar entendimentos específicos; b) tais princípios deveriam incluir o de "não-imposição de prejuízos” aos demais ribeirinhos; c) os ribeirinhos interessados deveriam ser notificados (por oposição a previamente consultados) da realização de obras sobre o leito dos rios internacionais; d) o status de rio internacional valeria apenas para o rio, e não para seus afluentes; e) o conceito de "Estado ribeirinho" deveria ser diferente de "Estado interessado", cabendo apenas ao primeiro tipo o princípio da soberania compartida. Cf. Parecer do Consultor Jurídico do Ministério das Relações Exteriores, Brasília, 6 de janeiro de 1965, AAS, 1969.01.15. CPDOC/FGV.

45 Ainda em 1932, a Comissão Permanente de Direito Internacional Público do Rio de Janeiro (foro composto por proeminentes internacionalistas brasileiros tais como Clóvis Benvilacqua, Epitácio Pessoa, Eduardo Espínola e Prudente de Moraes) sustentava que, se um rio fosse fronteiriço, nenhum Estado poderia alterar seu curso sem consultar e obter o consentimento dos outros Estados afetados. Um ano mais tarde, esse princípio deu forma à Declaração de Montevidéu sobre a Utilização Industrial e Agrícola dos Rios Internacionais, que o Brasil não somente assinou como patrocinou. Ver CANO, G. J. Argentina, Brazil and the de La Plata River Basin: a summary review of their legal relationship. Natural Resources Journal,1976. p. 863-881. Segundo Maria Regina de Soares Lima, o Brasil teria assinado essa Declaração porque não existiam ainda condições técnicas de realizar construções significativas sobre o leito dos rios internacionais que cortam o Brasil, além de que naquela conjuntura particular o Brasil era mais fraco do que a Argentina. Ver LIMA, M. R. S. de, The political economy of Brazilian foreign policy: nuclear policy, trade and Itaipu. 1986. Tese (Doutorado) - Vanderbilt University. p. 361.

LANÚS. Op. Cit., p. 299-300.

COSTA, L. A. P.; RUDA, J.M. Derecho Internacional Público. Buenos Aires: TEA, 1979. Apud. LANÚS. Op. Cit., p. 316.

48 Assinado em 28 de junho de 1919, estabelecia que a perturbação da navegação nos trechos internacionais por parte de obras sobre os rios Oder, Elba, Niemen e Danúbio poderiam levar a Corte Pernamente de Justiça Internacional a suspender os trabalhos. LANÚS. Op. Cit., p. 315. Subscrito em 1963 entre Camarões, Chade, Daomé (Benin desde 1976), Guiné, Costa do Marfim, Mali, Níger, Nigéria e Alto Volta (Burkina Faso desde 1984), afirma que os países se comprometem a cooperar "no estudo e execução de qualquer projeto que possa ter efeito apreciável sobre qualquer aspecto do curso do rio Níger, seus tributários, suas condições de navegação, exploração agrícola e industrial, condições sanitárias das águas e as características biológicas de sua fauna e flora [minha tradução]”. Apud. LANÚS. Op. Cit., p. 315. 
52 Silveira (1917-1990) ingressou na carreira diplomática aos 26 anos de idade e a deixou aos 68. Serviu como terceiro e segundo secretário nas embaixadas de Havana (1945-1949) e Buenos Aires (1949-1950), foi primeiro secretário em Madrid (1954-1956) e Roma (1957-1958) e Cônsul em Florença (1956-1957). Ocupou diversos cargos na administração do Itamaraty, dos quais destaca-se a chefia do Departamento de Administração (1959-1961 e 1963-1966). Entre 1966 e 1968 chefiou a delegação brasileira em Genebra. Foi embaixador em Buenos Aires (19691974), em Washington (1979-1982) e em Lisboa (1982-1985). Entre 1974 e 1979 foi ministro de Estado das Relações Exteriores.

53 Depoimento, cassete $n^{\circ} 1$, lado A, 10 maio 1979.

54 La Prensa, 10 de julho de 1971.

55 Ver MRE à legação em Buenos Aires, telegrama secreto, Brasília, 22 de julho de 1971, n 535, AAS, 1969.01.15. CPDOC/FGV; Silveira ao MRE, telegrama, Buenos Aires, 22 de novembro de 1971, n 2097, AAS, 1969.09.02. CPDOC/FGV. O texto menciona que é objetivo comum impulsionar a integração física de ambos países, que seriam "parte da zona andina da Bacia do Plata [minha tradução]”.

56 Silveira ao MRE, telegrama secreto urgentíssimo, Buenos Aires, 26 de julho de 1971, $\mathrm{n}^{\circ}$ 1237, AAS, 1969.01.15. CPDOC/FGV.

57 O discurso de Geisel na primeira reunião de gabinete, em 19 de março de 1974, já traz esses elementos. O mesmo ocorreu com Silveira em seu discurso de posse, no qual prenunciou os novos tempos ao afirmar que "o Brasil não se contém apenas no inventário de suas dimensões presentes, mas antes se completa na perspectiva fecunda da superação do que é hoje (...) Por isso, [o Itamaraty] tem feito e continuará a fazer ajustamentos sistemáticos na sua capacidade de atuar”. BRASIL. Ministério das Relações Exteriores. Resenha de Política Exterior. Brasília: MRE. $n^{\circ}$ 1, mar/abr/maio/jun 1974, p. 9 e 19-20. Nessa mesma ocasião Silveira afirmou a seus colegas que “a melhor tradição do Itamaraty é saber renovar-se”. À luz do Depoimento, é praticamente impossível saber se essa construção tinha por objetivo contemporizar a postura do ministro com eventuais críticas dos setores mais conservadores da Casa ou se foi uma ironia do ministro endereçada a esses grupos. Provavelmente tratou-se de uma conjunção das duas alternativas.

58 Segundo Silveira, o texto por ele preparado para leitura do mandatário durante a primeira reunião de gabinete, em 19 de março de 1974, trazia a noção de “pragmatismo responsável”, mas não definia a expressão - tarefa que ficou por conta de Geisel. Inclusive, para o diplomata teria sido melhor se a expressão a qualificar a política externa brasileira houvesse ressaltado o lado ecumenista do projeto, e não o pragmático. Depoimento, cassete nº 2, lado A, 10 maio 1979.

59 Passim. CERVO, O desafio... e VIZENTINI, A política externa...

60 Há indícios de que Pinochet teria realizado esforços para ser convidado à festa, que foi sua primeira viagem internacional oficial. Geisel e Silveira teriam evitado encontros com o presidente chileno ao longo de todo a gestão, uma vez que isso associava o mandatário brasileiro ao brutal golpe de Estado perpetrado pelo colega em 1973. CHIARELLI, Marilena. Entrevista concedida ao autor. Brasília: 15 de agosto de 2001. (Marilena Chiarelli foi a jornalista responsável, da Rede Globo, pela cobertura da política externa durante o governo Geisel).

61 Os entendimentos diplomáticos de caráter econômico já existiam com Bolívia e Uruguai. A ocasião serviu para que Geisel propusesse pesada agenda econômico-comercial, ver Merquior a Embaixador Pereira de Araujo, memorando confidencial, Brasília, 2 de abril de 1974, AHMRE, caixa C-01.

62 Esse boato foi difundido nas imprensas argentina e brasileira, ver La Opinión, Buenos Aires, 28 de fevereiro de 1974, e O Estado de S. Paulo, 17 e 23 de março de 1974.

63 ACUÑA, C. La nueva matriz política argentina. Buenos Aires: Nueva Visión, 1995. p. 13

64 CERVO. Relações internacionais... p. 245-247.

65 PUIG. Op. Cit., p. 39. 
66 Para Carlos Escude, o “nacionalismo territorial argentino” é uma característica cultural daquele país, assentada sobre a percepção de que, durante a história da formação nacional, houve perda real de território para outros países. Ver ESCUDÉ, C. El Nacionalismo Territorial Argentino. In: PERINA; RUSSEL, Op. Cit., p. 241.

67 Siete Días, 19 a 25 de janeiro de 1978.

68 NEILSON, J. Editorial. The Buenos Aires Herald. Buenos Aires, 11 mar. 1976.

69 Oscar Hector Camilión nasceu em Buenos Aires, em 1930. Foi professor da Faculdade de Direito da Universidade de Buenos Aires, onde ocupou o cargo de Secretário Geral e iniciou a carreira política (1955). Ensinou política internacional no Instituto Argentino de Cultura Hispânica (1967-1971) e no Curso Superior de Defesa Nacional da Escola Nacional de Guerra (1973). Aos 28 anos era chefe da Divisão de Pessoal da chancelaria argentina (1958), cargo que acumulou mais tarde como Chefe de Gabinete do Ministro (1959). No auge do governo de Arturo Frondizi, foi Subsecretário de Relações Exteriores e Ministro na embaixada argentina no Rio de Janeiro (1959-1962). Entre 1965 e 1972 foi Chefe de Redação de El Clarín. Entre 1976 e 1979 foi embaixador argentino junto ao governo do Brasil. Em 1981 foi alçado ao cargo de ministro das relações exteriores do governo Viola (1981). Ao longo da década de 1980 foi enviado especial do Secretário Geral das Nações Unidas para o Chipre. Deixou esse cargo para ocupar o Ministério de Defesa na gestão Menem.

70 Ao chegar à embaixada em Brasília, Camilión ouviu do adido militar argentino que, caso não houvesse um avanço significativo nas negociações, "seria necessário bombardear Itaipu”. CAMILIÓN, Oscar. Memórias Políticas: de Frondizi a Menem, 1956-1996. Buenos Aires: Planeta, 1999, p. 205-208.

71 Espírito de Uruguaiana foi o nome dado ao conjunto de acordos assinados por Jânio Quadros e Arturo Frondizi, discriminados a seguir: Convênio de Amizade e Consulta; Declaração Presidencial Conjunta; Declaração Econômica; e Declaração sobre Intercâmbio Cultural, celebrados na cidade fronteiriça de Uruguaiana (Rio Grande do Sul) entre 20 e 22 de Abril de 1961. A esses documentos, somam-se a Declaração Conjunta, o Tratado de Extradição e a Convenção sobre Assistência Judiciária Gratuita que o chanceler San Tiago Dantas assinou com seu par argentino, Miguel Cárcano, em novembro do mesmo ano. Cf. Capítulo 1.

72 Sobre a autonomia de Camilión, vale notar que ele afirma nunca ter recebido nenhuma diretriz da Junta ou do chanceler argentino. Atribui isso ao fato de que o governo de Buenos Aires sabia que à medida que o relacionamento argentino-chileno se deteriorava, era necessário manter uma postura positiva com o Brasil, CAMILIÓn, Memórias... p. 193. Adiante, mostra-se que efetivamente Camilión gozava de menos autonomia do que as suas Memórias sugerem.

SILVEIRA, A. F. A. da. O Brasil e a nova ordem internacional. Revista Brasileira de Política Internacional, ano 18, $\mathrm{n}^{\circ}$ 69/72, 1975. p.8.

74 Depoimento, cassete $n^{\circ} 12$, lado B, 1 jun. 1979, 1 jun. 1979.

75 Em um ato curioso, senão constrangedor, o núncio apostólico, que representava as delegações presentes, respondeu ao Presidente fazendo defesa do caso argentino. "[Hoje] a teoria dos Estados estanques fatalmente cede o posto à do intercâmbio universal. A individualidade deu lugar à coletividade (...) em virtude disso, os acontecimentos de um país, favoravelmente ou não, causam reflexos sobre os outros, a ponto de tanger o conjunto total do mundo”. In: GEISEL: alarde não ajuda diplomacia. O Estado de S. Paulo, 11 maio 1977.

76 Ver exposição feita na Comissão de Relações Exteriores da Câmara dos Deputados pelo ministro Rubens Ricúpero, Chefe da Divisão da América Meridional-II do Ministério das Relações Exteriores, 9 de maio de 1979. In: Relações Internacionais, nº 5, vol. 3, junho, 1980.

77 BANDEIRA, 0 eixo...

78 Em relação à Bolívia, vale notar a ratificação do Acordo de Cooperação e Complementação Industrial (22 de maio de 1974). Com o Uruguai, o Tratado da Lagoa Mirim (20 de maio de 1974), o Tratado de Amizade, Cooperação e Comércio (Tratado de Rivera, 12 de junho de 
1975), o Acordo sobre Trigo (7 de março de 1975) e a viagem oficial de Geisel àquele país em 24 de janeiro de 1978. BRASIL. Resenhas de Política Exterior do Brasil. Brasília: MRE. nº 1, 3, 4, 5 e $16(1974,1975$ e 1978).

79 GÓES. O Brasil..., p. 54 e CONDE, C. Militares assumem a ação diplomática. O Estado de S. Paulo, 10 jul. 1977.

80 LA VISITA de um Almirante y la “cruzada” del Brasil. Revista Confirmado, maio 1976.

81 Política Internacional, ago/sep, 1977.

82 FOULKES. Haroldo. Buenos Aires-Brasília: eje torcido, rueda loca. Revista Panorama, agosto 1977. p. 14-16.

83 CAMILIÓN. Memórias..., p. 202.

84 Ibid. p. 203.

85 Id.

86 Dizia o influente Última Clave: “O camilionismo desacreditou com simplicidade inexplicável a tese que recomendava uma maior contundência em nossas relações com o Brasil e com os países que operavam como satélites do grande sol de Brasília (...) o camilionismo fracassou peremptoriamente em sua tentativa de docificar as relações bilaterais. Sua alquimia, que consiste em transformar vinagre em mel [resultou em] desprezos públicos e patentes aos esforços de alto nível por juntar Geisel com Videla e fortes pressões sobre Mendez e Stroessner para que abandonassem definitivamente a idéia de apostar parte de seu capital político em Buenos Aires [minha tradução]”. Um editorial da revista Cabildo chegava a afirmar que Camilión tinha sido irresponsável ao sugerir uma cota de reagente de 104 metros, ao apoiar a doutrina brasileira de fazer de Itaipu um fato consumado e fazer de Stroessner, mandatário de uma nação menor, o mediador entre Buenos Aires e Brasília. NUESTRA politica exterior. Última Clave, Buenos Aires, 18 junio 1977, p. 5-8; COINCIDENCIAS y disensos internacionales. Última Clave, Buenos Aires, 27 junio 1977, p. 5-7; e ANTE un grave peligro. Revista Cabildo, abril 1978, p. 5-6.

87 Conforme apresentado no Capítulo II, Frondizi foi acusado de “entreguista” por certos setores argentinos que sugeriam ser os convênios de Uruguaiana um instrumento do Itamaraty para forçar Buenos Aires a uma postura “mais neutralista” face à revolução cubana.

88 Silveira a Geisel, informação secreta exclusiva para o Senhor Presidente da República, Brasília, 15 de agosto de 1978, n 219, AAS. CPDOC/FGV.

89 AS DUAS turbinas da discórdia. Isto É, 31 out. 1978. p. 13-14 e ITAMARATY fracassa outra vez em Itaipu. Isto É, 28 de fevereiro de 1979. p. 10-11.

90 Henry Kissinger foi Assessor para a Segurança Nacional do presidente norte-americano Richard Nixon entre 1969 e 1972. Em seguida, foi alçado ao posto de Secretário de Estado, no qual permaneceu durante todo o governo de Gerald Ford (1973-1977).

91 Presidente norte-americano entre 1977 e 1981.

92 LESSA, A. C. A diplomacia universalista do Brasil: a construção do sistema contemporâneo de relações bilaterais. Revista Brasileira de Política Internacional. a. 41, número especial 40 anos, 1998, p. 35.

93 A mobilização dos dois governos ao tempo das viagens de Figueiredo à Argentina, assim como as demonstrações de admiração da população argentina nas ruas e nos eventos públicos, relembra os picos de entendimento bilateral dos únicos dois mandatários brasileiros a visitar oficialmente o país vizinho ao longo do século XX: Campos Sales (1902) e Getúlio Vargas (1935). GUERREIRO. Op. Cit., p. 97 e 98.

94 Esses são os critérios contra os quais se mensura, segundo Lessa, a formação de uma parceria estratégica, que são: "Relações políticas e econômicas prioritárias reciprocamente remuneradoras, constituídas a partir de um patrimônio de relações bilaterais universalmente configurado. A construção de parcerias estratégicas é fruto da compatibilização da vocação histórica do Brasil para a universalidade com a necessidade de aproximações seletivas, o que abre a possibilidade 
para movimentos de adaptação aos nichos de oportunidade e aos constrangimentos internacionais que se apresentam conjunturalmente”. LESSA. A diplomacia universalista..., p. 30.

Brasileira de Política Internacional. a. 44, $\mathrm{n}^{\circ}$ 2. 2001. p.153.

Resumo

Este artigo busca identificar os fatores que concorrem para explicar a mudança no eixo entre a Argentina e o Brasil, no começo da década de 1980, quando as duas diplomacias convergiram em um projeto de integração inovador. $\mathrm{O}$ argumento apresentado defende que a aproximação entre os dois países foi o legado, inesperado, do relacionamento bilateral ao longo da gestão do Presidente Geisel (1974-1979).

\section{Abstract}

This article aims at identifying which factors lay behind the sudden change in Argentine-Brazilian relations in the early 1980s, when their foreign policies converged into an innovative integration project. The argument put forward is that convergence between the two countries was the unintended legacy of their bilateral interaction during President Geisel’s administration (1974-1979).

Palavras-chave: Política externa; Argentina; Brasil; Ernesto Geisel; Pragmatismo Responsável; Antônio Francisco Azeredo da Silveira; Integração regional. Key words: Foreign Policy; Argentina; Brazil; Ernesto Geisel; Responsible Pragmatism; Antônio Francisco Azevedo da Silveira; Regional Integration. 